\title{
Effect of Ultrasonic Treatment Parameters on Microstructural and Mechanical Properties of A356 Aluminum Alloy
}

\author{
Esra Dokumac1 ${ }^{1}$, Uğur Aybarç ${ }^{2 *}$, Kazım Önel $^{1}$ \\ 0000-0003-3886-3963, 0000-0002-5646-351X, 0000-0003-2191-4867
}

${ }^{1}$ Metallurgical and Materials Engineering, Dokuz Eylül University, 35397, Turkey

${ }^{2}$ CMS Jant ve Makina San. A.S., ArGe Merkezi, 35620, Turkey

\begin{abstract}
The aim of this study is to investigate the effect of ultrasonic treatment on the microstructural and mechanical properties of A356 aluminum alloy. Ultrasonic treatment was applied to $2 \mathrm{~kg}$ and $4 \mathrm{~kg}$ molten metals at different melting temperatures $\left(700{ }^{\circ} \mathrm{C}, 720^{\circ} \mathrm{C}\right.$ and $\left.740{ }^{\circ} \mathrm{C}\right)$ for different durations $(0,60,180$ and 300 seconds). Bifilm indices of the samples were also measured after all parameters were tested. The ultimate tensile strength (UTS) and elongation values were used to calculate the Quality Index (QI) of the samples. According to the results, the amount of liquid metal directly affects the the ultrasonic intensity that is produced during the treatment. Maximum UTS and elongation results were determined at $720^{\circ} \mathrm{C}$ during 300 seconds for $4 \mathrm{~kg}$ casting. Minimum bifilm density value was measured at the same ultrasonic temperature and time.
\end{abstract}

Keywords: Ultrasonic treatment, Aluminum alloy, Bifilm index, Quality index

\author{
* Corresponding author \\ Uğur AYBARÇ \\ uaybarc@cms.com.tr
}

Adress: CMS Jant ve Mak. San. A.Ş. A.O.S.B. 10006/1 Sok. No:12 35620 Çiğli / İzmir

Tel:+905339383835

Fax: +902323991111

Researh Article

$\begin{array}{ll}\text { Manuscript } & \\ \text { Received } & 01.10 .2019 \\ \text { Revised } & 03.09 .2020 \\ \text { Accepted } & 04.09 .2020\end{array}$

Doi: 10.30939/ijastech..627422

\section{Introduction}

Because of the properties such as low density, corrosion resistance, good strength and castability, aluminum (Al) alloys have been the most popular materials and found wide range of applications for decades. Components made of $\mathrm{Al}$ alloys are generally critical parts of aerospace and automobile industries in terms of high safety requirements. Therefore, the mechanical properties of $\mathrm{Al}$ alloys have to meet strict specifications and the keys to obtain them are the manufacturing and treatment processes [1-5]

Pores in a cast may serve as crack initiators and affect the mechanical properties negatively [6]. Catastrophic failure is inevitable for a component with high porosity. It is clear that porosity of the cast is the major problem due to high solubility of hydrogen in molten aluminum [7-9]. Because of the reaction between aluminum and air humidity (Equation 1), an oxide film is formed and entrained into the melt. It makes two non-wetting surfaces, known as bifilm, as shown in Fig. 1 [10-12].

$$
2 \mathrm{Al} \text { (liquid) }+3 \mathrm{H}_{2} \mathrm{O}(\text { gas }) \rightarrow \mathrm{Al}_{2} \mathrm{O}_{3}(\text { solid })+6 \mathrm{H}
$$

Therefore, degassing process and grain refinement treatment are the most important operations affecting the performance of casting process [1]. There are various processes to reduce hydrogen amount in molten aluminum, such as; hexachloroethane $\left(\mathrm{C}_{2} \mathrm{Cl}_{6}\right)$ pellets, vacuum degassing [7] and ultrasonic degassing [13-15]. The first mentioned degassing process is harmful for the environment [16] due to the release of dangerous $\mathrm{Cl}_{2}$ gases into the atmosphere [17]. On the other hand, the vacuum degassing method is a high cost method for the initial installation [7]. But, ultrasonic degassing is an environmentally clean technique [6].

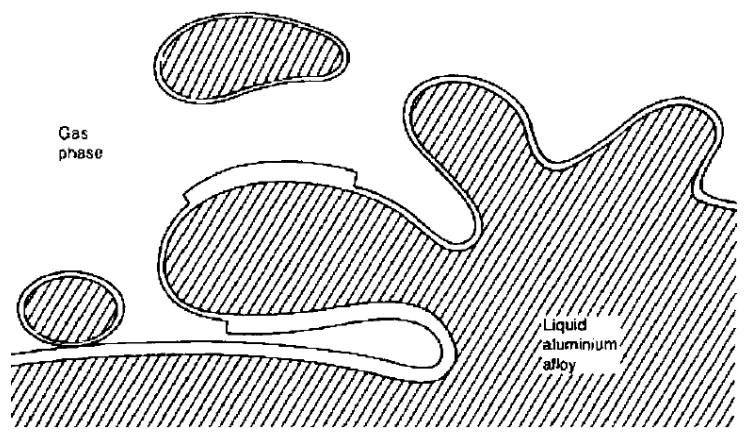

Fig. 1. Schematic representation of bifilm formation into the melt [10]

In the ultrasonic degassing methods, high intensity 
vibration is applied to molten aluminum to generate oscillating pressure fields which create large number of small cavities in the melt. These numerous cavities promote the hydrogen diffusion from molten aluminum to the developed bubbles which coagulate and float to melt surface [18-20]. In the literature, there are various studies investigating the effects of parameters of ultrasonic treatment on microstructure and mechanical properties of casting alloys. $\mathrm{Xu}$ et al [7] investigated the degassing effect of ultrasonic treatment at different temperature $\left(620,660,700\right.$ and $\left.740^{\circ} \mathrm{C}\right)$ for different amounts of molten A356 aluminum alloy (0.2, 0.6 and $2 \mathrm{~kg}$ ). They only used reduce pressure test (RPT) to evaluate the density of samples. They deduced that ultrasonic treatment has significant effect on degassing process especially at the higher temperatures such as between 700 and $740{ }^{\circ} \mathrm{C}$. And additionally, the ultrasonic process was more effective on the smallest amount of melt. Jia et al [21] studied the effect of ultrasonic treatment on the grain refinement of A356 aluminum alloy. Tests were performed on $3 \mathrm{~kg}$ of molten alloy at $750^{\circ} \mathrm{C}$ for $15 \mathrm{~min}$. To analyze the efficiency of ultrasonic vibration, they prepared samples with and without ultrasonic treatment. And they concluded that UTS, YS and elongation values increased from 228 $\mathrm{MPa}, 180 \mathrm{MPa}$ and $4 \%$ to $190 \mathrm{MPa}, 250 \mathrm{MPa}$ and $4.9 \%$, respectively. $\mathrm{Li}$ et al [22] investigated the influence of ultrasonic treatment time $(0,60,120,180,240 \mathrm{~s})$ and the cooling condition on the gas content of aluminum alloy through the ingot density. In all studies, the results are evaluated by measuring gas content and density by using RPT test method.

In addition to these related literatures, in this study the effects of ultrasonic treatment are investigated at different temperatures with different duration. The higher amount of molten metal was also used in the experimental studies and the effects of all parameters on microstrucure and mechanical properties are examined together. Bifilm analysis was conducted and the relationship between bifilm content and mechanical properties was discussed. Ultimate tensile strength and elongation values were used to calculate the Quality Index (QI) of A356 alloy as shown in the Equation 2 [22,23,36].

$$
Q I=U T S+K * \log (\text { elongation })
$$

Abbreviations denoted by QI, UTS and $\mathrm{K}$ represent quality index, ultimate tensile strength and constant (150 $\mathrm{MPa}$ for A356), respectively.

QI is demanded by engineers to analyze if mechanical properties of alloys are suitable with working condition or not, especially in automotive and aerospace industry [24]. So this index can be used to evaluate alloys properties.

\section{Experimental Procedure}

Chemical analysis of the ingots used in this study was obtained with a commercial optical emission spectrometer. The chemical composition of A356 alloy ingots is given in Table 1.

Table 1. Chemical composition of A356 alloy
\begin{tabular}{c|c|c|c|c|c|c|c|c}
$\begin{array}{c}\text { Ele- } \\
\text { ment }\end{array}$ & $\mathrm{Al}$ & $\mathrm{Cu}$ & $\mathrm{Fe}$ & $\mathrm{Mg}$ & $\mathrm{Mn}$ & $\mathrm{Si}$ & $\mathrm{Ti}$ & $\mathrm{Zn}$ \\
\hline $\begin{array}{c}\text { Content } \\
\text { (wt \%) }\end{array}$ & 92 & 0.1 & 0.1 & 0.3 & 0.05 & 7.3 & 0.1 & 0.05
\end{tabular}

Two different crucibles were prepared with $2 \mathrm{~kg}$ and $4 \mathrm{~kg}$ of A356 ingot pieces to determine the effect of charge amount to the performance of ultrasonic degassing treatment. For each casting process, ingot pieces were weighed and held in a graphite crucible and melted in the electric furnace at different temperature $\left(700,720\right.$ and $\left.740^{\circ} \mathrm{C}\right)$. After melting, a Rtul model ultrasonic equipment (Fig. 2) which consists of an ultrasonic generator, a transducer, a booster and a horn is submerged into the crucible for degassing process. This equipment is capable of converting $3 \mathrm{~kW}$ of electric energy at a constant resonant frequency of $19.8 \mathrm{kHz}$.

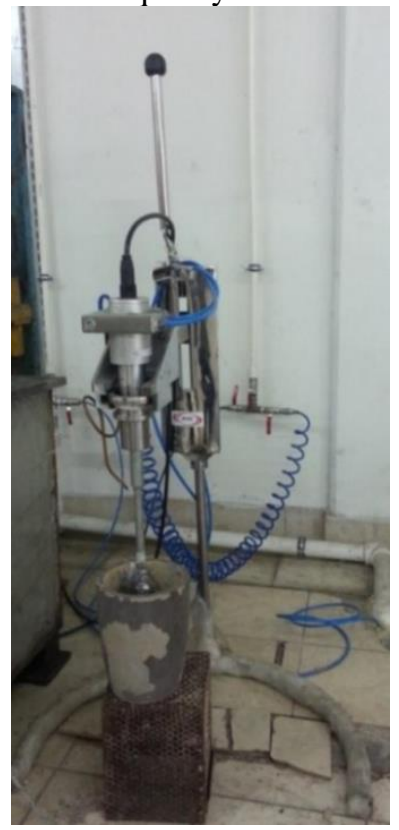

Fig. 2. Ultrasonic degassing equipment

Degassing process is performed at temperatures mentioned above during 60, 180 and 300 seconds. Casting samples without degassing were also prepared for comparison. Molten metal was poured into a bifilm mold (Fig. 3a) and a permanent mold (Fig. 3b) preheated to $340^{\circ} \mathrm{C}$. 


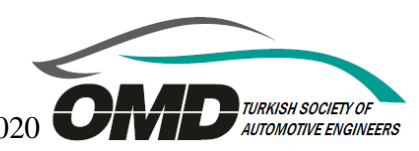

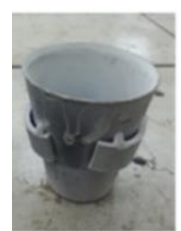

(a) (1)

(c)

Fig. 3. a) Bifilm test mold, b) permanent mold and c) bifilm test sample

Bifilm test samples (one sample for each condition) were prepared under 80 mbar vacuum for 8 seconds by an Ideco reduced pressure test (RPT) equipment. Clemex Vision Lite software was used to measure bifilm index on sectioned bifilm test samples seen in Fig. 3c. T6 heat treatment process was applied to all samples at three steps; solutionizing step was applied at $540^{\circ} \mathrm{C}$ for 4 hours, quenching step was addressed in water at $80^{\circ} \mathrm{C}$ and all in all artificially aging step was studied at $155^{\circ} \mathrm{C}$ for 3 hours. Samples for mechanical tests and microstructural examination were taken from permanent mold cast sample shown in Fig. 4a. For each test condition 5 different samples were prepared for tensile test. For microstructural examination, surfaces of the samples were prepared by grinding with $\mathrm{SiC}$ paper and polishing with diamond paste for microstructural analysis. For macro and micro examination, etching solution consisted of $\mathrm{FeCl} 3$ and $0.5 \% \mathrm{HF}$ were used, respectively. Tensile test samples (Fig. 4b) were prepared in accordance with DIN EN ISO 6892-1. Tensile tests were performed by a Zwick Z100 Model tensile test machine with DIN EN 10002-1 test standard (as preload: $5 \mathrm{~N} / \mathrm{mm} 2$, test speed: $4.2 \mathrm{~mm} / \mathrm{min}$.).

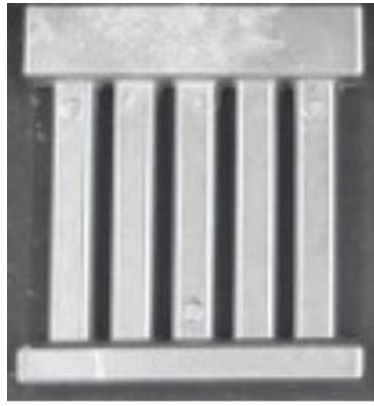

(a)

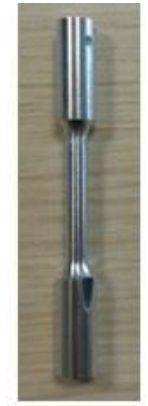

(b)
Fig. 4. a) Cast sample mold and b) tensile test sample

\section{Results and Discussion}

Macrographs of the samples for $2 \mathrm{~kg}$ and $4 \mathrm{~kg}$ charged castings are given in Fig. 5 and Fig. 6.

According to the macrostructure it can be said that grain size is getting smaller by increasing ultrasonic treatment duration. Linear intercept method was used to measure the grain size of samples. The grain sizes of the samples produced with $2 \mathrm{~kg}$ at $740^{\circ} \mathrm{C}$ were measured as $1940,6 \mu \mathrm{m}$ and $1125,6 \mu \mathrm{m}$ for the samples without ultrasonic application and for 300 seconds ultrasonic application, respectively. The grain sizes of the samples produced with $4 \mathrm{~kg}$ at $740^{\circ} \mathrm{C}$ were measured as $2062,6 \mu \mathrm{m}$ and $906,2 \mu \mathrm{m}$ for the samples without ultrasonic application and for 300 seconds ultrasonic application, respectively. Jian et al [25] investigated the effect of different types of power ultrasound on solidification of A356 alloy as continuous, intermittent and isothermal processing. They declared that the average grain size reduces by intermittent acoustic vibration. Because while the latent heat is being released during decreasing the melt temperature, ultrasonic vibration assists to prevent the local heating up and allow for occurring heterogeneous nucleation [26]. So, ultrasonic vibration is firstly to generate the initial crystallites and activation of potential nucleation sites in melt volume [27]. Reduction of grain size is described by two mechanisms that cause cavitation-enhanced nucleation and cavitation-induced dendrite-fragmentation [28,29]. Also cavitation promotes to wet of non-metallic inclusions and decrease porosities [30].

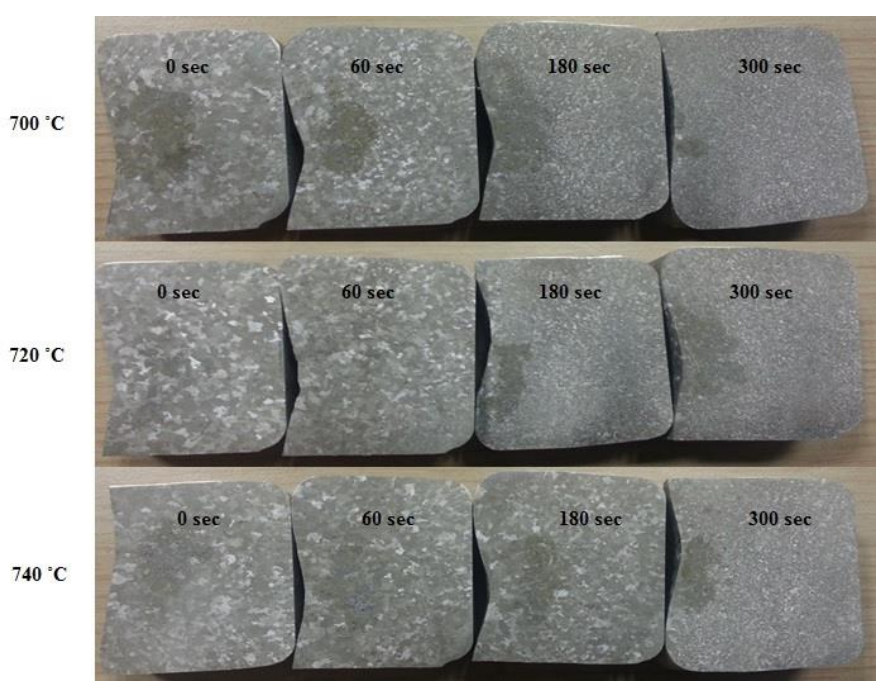

Fig. 5. Macrostructure of the $2 \mathrm{~kg}$ casting samples after ultrasonic treatments 


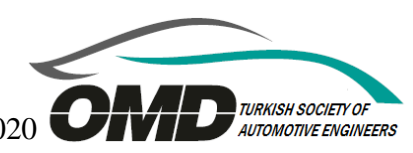

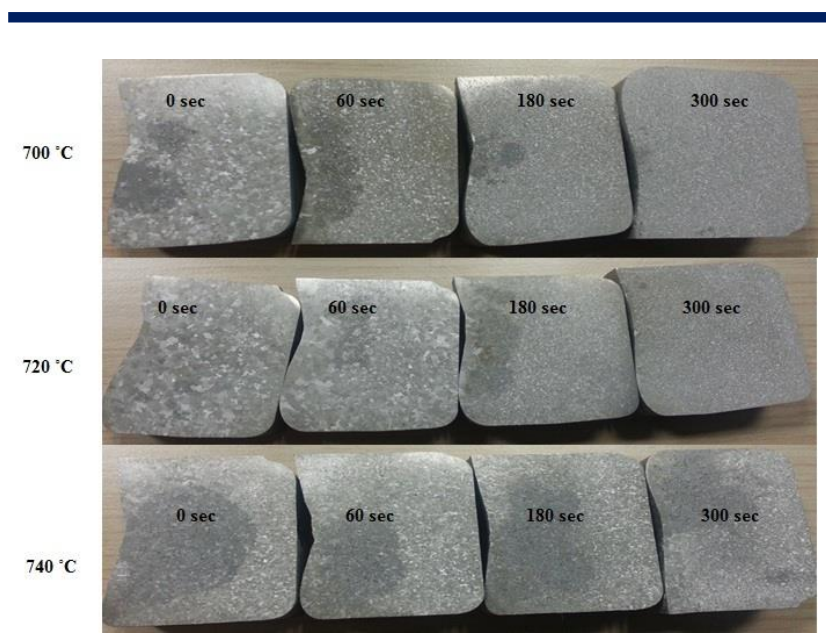

Fig. 6. Macrostructure of the $4 \mathrm{~kg}$ casting samples after ultrasonic treatments

The grain size of the samples which were ultrasonically treated at $700^{\circ} \mathrm{C}$ and $740^{\circ} \mathrm{C}$ for 300 seconds are $861,1 \mu \mathrm{m}$ and $1125,6 \mu \mathrm{m}$, respectively. This results show that low temperature has an additional effect on ultrasonic treatment in reducing grain size.

Micrographs of the samples for $2 \mathrm{~kg}$ and $4 \mathrm{~kg}$ castings are given in Fig. 7 and 8. According to the microstructural examination and some studies in the literature, it can be said that porosity decreases by increasing the ultrasonic treatment duration [20,31]. It can be clearly seen in Fig. 7 that dendirites are getting smaller with decreasing temperature and increasing duration. This can be explained by the inverse relationship between temperature and viscosity. It can be calculated theoretically by using Arrhenius as Equation 3 [32].

$$
\eta=\eta_{0} \exp \left(\frac{E}{R T}\right)
$$

$\eta_{0}$ : is a constant for a given liquid

E: activation energy for viscous flow of the liquid

$\mathrm{R}$ : universal gas constant

$\mathrm{T}$ : absolute temperature

In the literature, Dispinar has detailed how bifilm index could be calculated [9-12,33-35]. In this study, in order to determine the correlation between bifilm and mechanical test results, bifilm density was taken into account. Equation 4 was used to calculate bifilm density:

Bifilm Density $=\left(\frac{\text { Total Bifilm Lenght }}{\text { Scanning Field }}\right) * 100$

In Fig. 9, the change of the bifilm density with the ultrasonic treatment duration for $2 \mathrm{~kg}$ and $4 \mathrm{~kg}$ casting is given respectively. According to Fig. 9a, it can be seen that the bifilm density values vary irregularly. Since the amount of liquid metal in $2 \mathrm{~kg}$ casting is small, it fluctuates during ultrasonic treatment. In Fig. 9b, the bifilm density values decrease at $720^{\circ} \mathrm{C}$ and $740^{\circ} \mathrm{C}$ whereas these values increase at $700^{\circ} \mathrm{C}$ with increasing ultrasonic treatment duration (from $0 \mathrm{sec}$ to $300 \mathrm{sec}$ ).

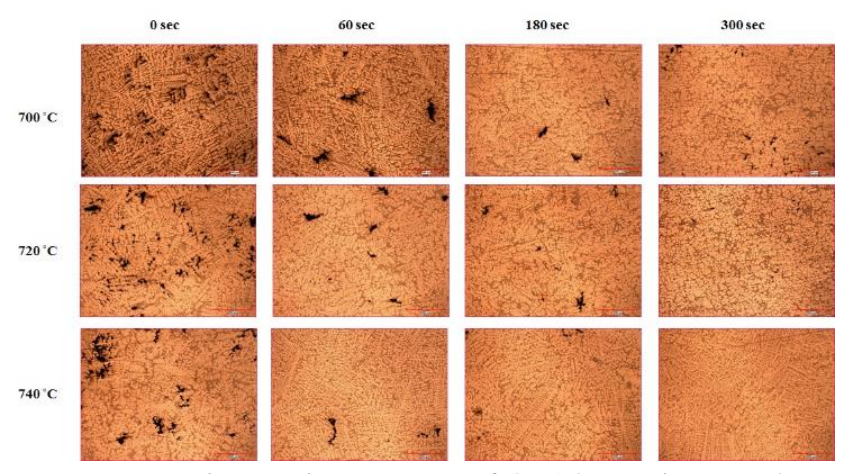

Fig. 7. Microstructure of the $2 \mathrm{~kg}$ casting samples after ultrasonic treatments

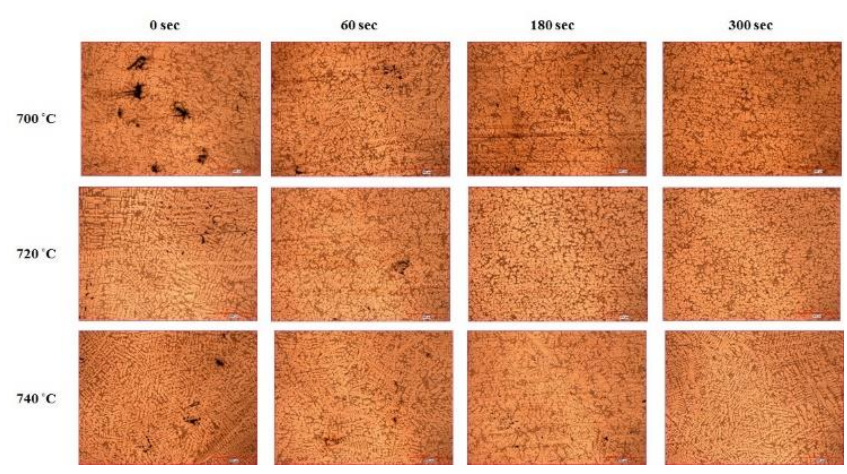

Fig. 8. Microstructure of the $4 \mathrm{~kg}$ casting samples after ultrasonic treatments

The change in ultimate tensile strength (UTS) values is irregular as well as bifilm density values for $2 \mathrm{~kg}$ casting (Fig. 10a). At $720^{\circ} \mathrm{C}$ and $740^{\circ} \mathrm{C}$ UTS values increase with ultrasonic treatment duration for $4 \mathrm{~kg}$ casting (Fig. 10b). When Fig. 9 and 10 are evaluated it can be said that there is an inverse relationship between bifilm density and UTS. This results are supported by the earlier researches $[9,11]$. All the test results are considered to determine the main effect of temperature, amount of molten metal and ultrasonic treatment duration on UTS. "Main effect plot" in Minitab is generally used to examine differences between level means for one or more factors. The effects of three different parameter (melt temperature, amount of aluminium and ultrasonic application time) on UTS value are taken into consideration in the current study. According to the graphic in Fig. 10c, it can be said that decreasing temperature increases the UTS value. Additionally, the amount of molten metal has the most important effect on UTS results. Porosity density values are higher for $2 \mathrm{~kg}$ compared to $4 \mathrm{~kg}$ casting. 
Because the amount of molten Al metal is low, for $2 \mathrm{~kg}$ casting molten metal is fluctuated by ultrasonic vibration and causes porosity formation. Also, with the increase in ultrasonic treatment duration, the inclusions at the bottom of the slag mix back into the melt even though the surface does not excessively fluctuate and the slag is not broken during the mixing process. For $4 \mathrm{~kg}$, this situation is not seen. It can be seen in Fig. 9 that bifilm value of the sample taken from a $2 \mathrm{~kg}$ casting mold is higher than that taken from a $4 \mathrm{~kg}$ casting mold. Mechanical test results affected negatively due to being of bifilm as discussed previously. The second significant effect is casting temperature and the last one is ultrasonic treatment duration.

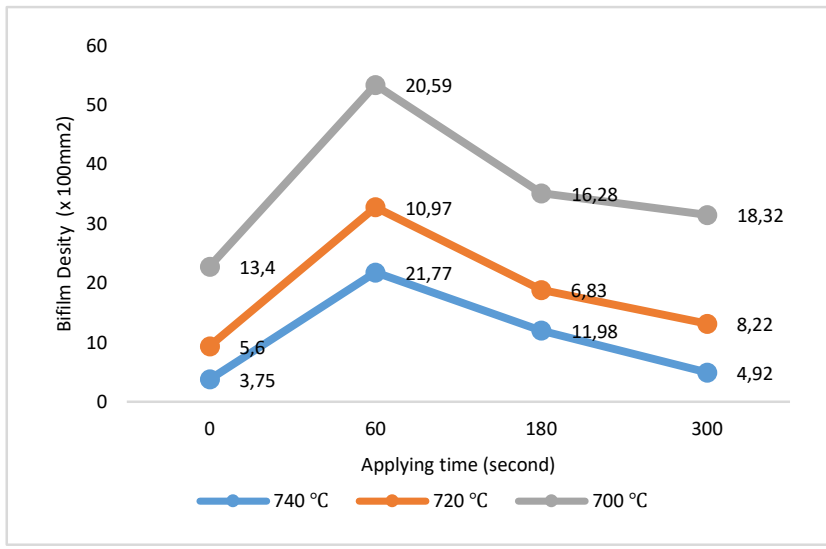

(a)

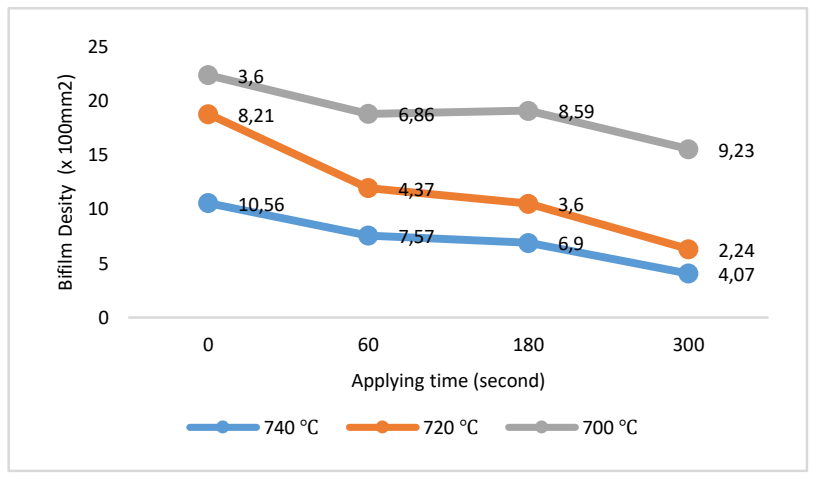

(b)

Fig. 9. Bifilm density values for a) $2 \mathrm{~kg}$ and b) $4 \mathrm{~kg}$ casting samples.

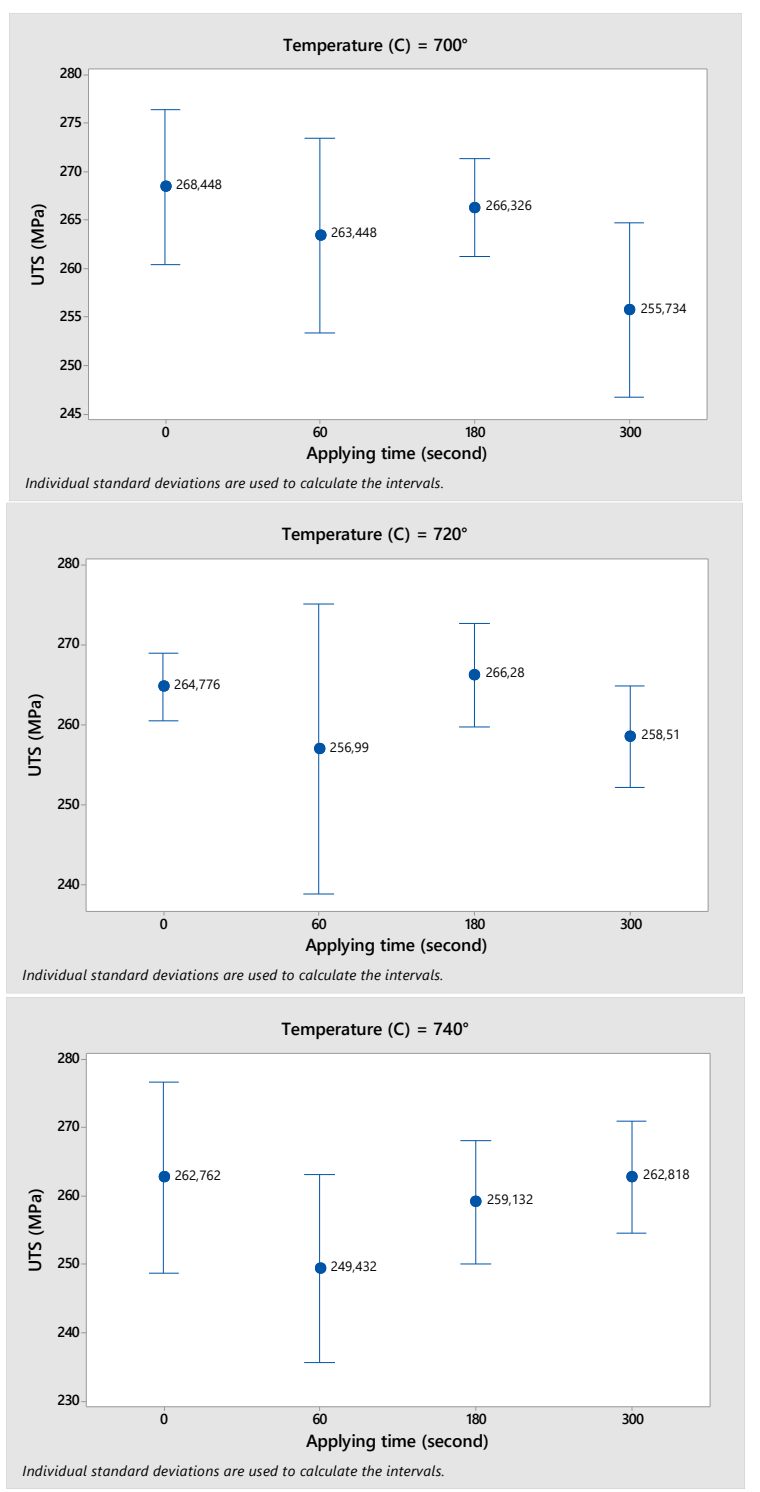

(a)

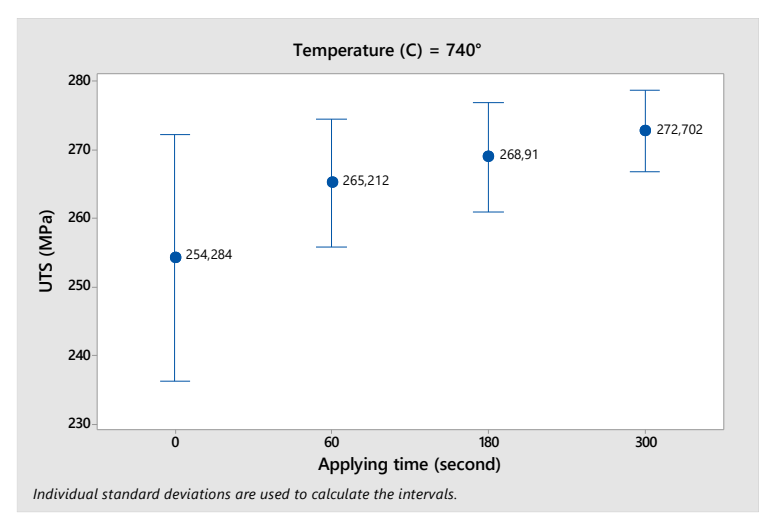




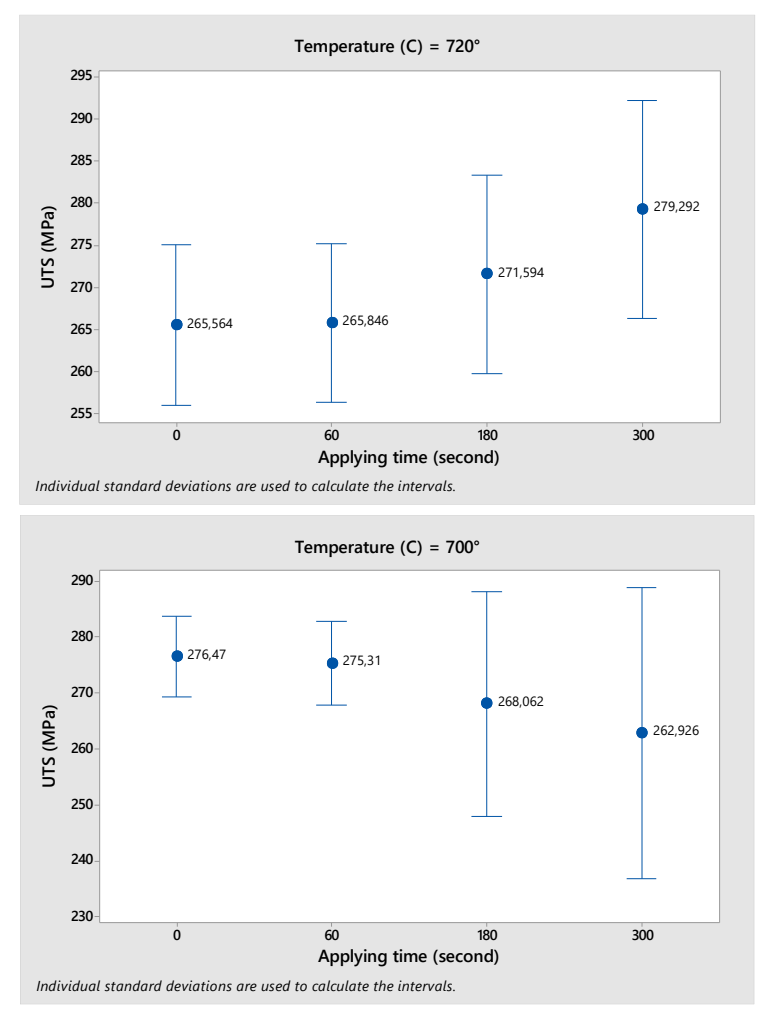

(b)

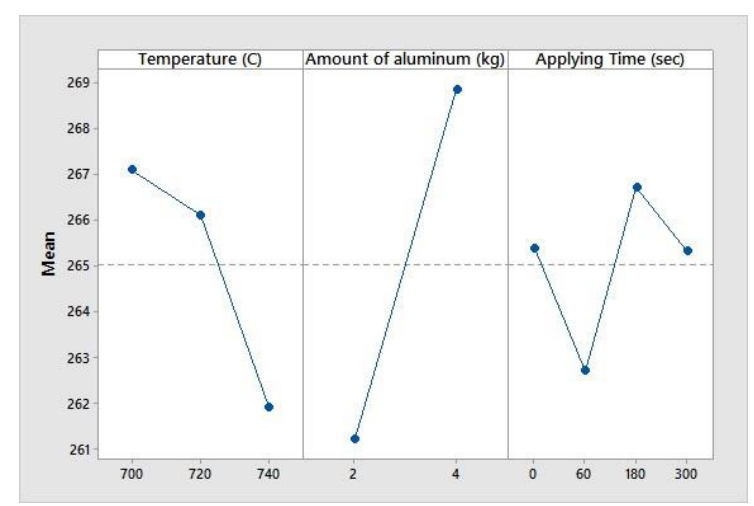

(c)

Fig. 10. Ultimate tensile strength values for a) $2 \mathrm{~kg}$, b) $4 \mathrm{~kg}$ casting samples and (c) main effect of temperature, amount of molten metal and ultrasonic applying time on UTS.
In Fig. 11, the change of elongation with time is given. The elongation value reaches its maximum value $7.59 \%$ at $720^{\circ} \mathrm{C}$ for $2 \mathrm{~kg}$ casting. For $4 \mathrm{~kg}$ casting, maximum elongation is $9.07 \%$ at $720^{\circ} \mathrm{C}$ for 300 seconds ultrasonic time. The results show that the increase in bifilm density leads to decrease in UTS and elongation [11,37].

Both ultimate tensile strength and elongation results were taken into account for the calculation of quality index (QI). These values are given in Fig. 12. It can be seen that ultrasonic treatment duration and temperature affect the mechanical test results significantly. The maximum values for UTS and elongation were reached at $720 \mathrm{oC}$ after 300 seconds for $4 \mathrm{~kg}$ casting.
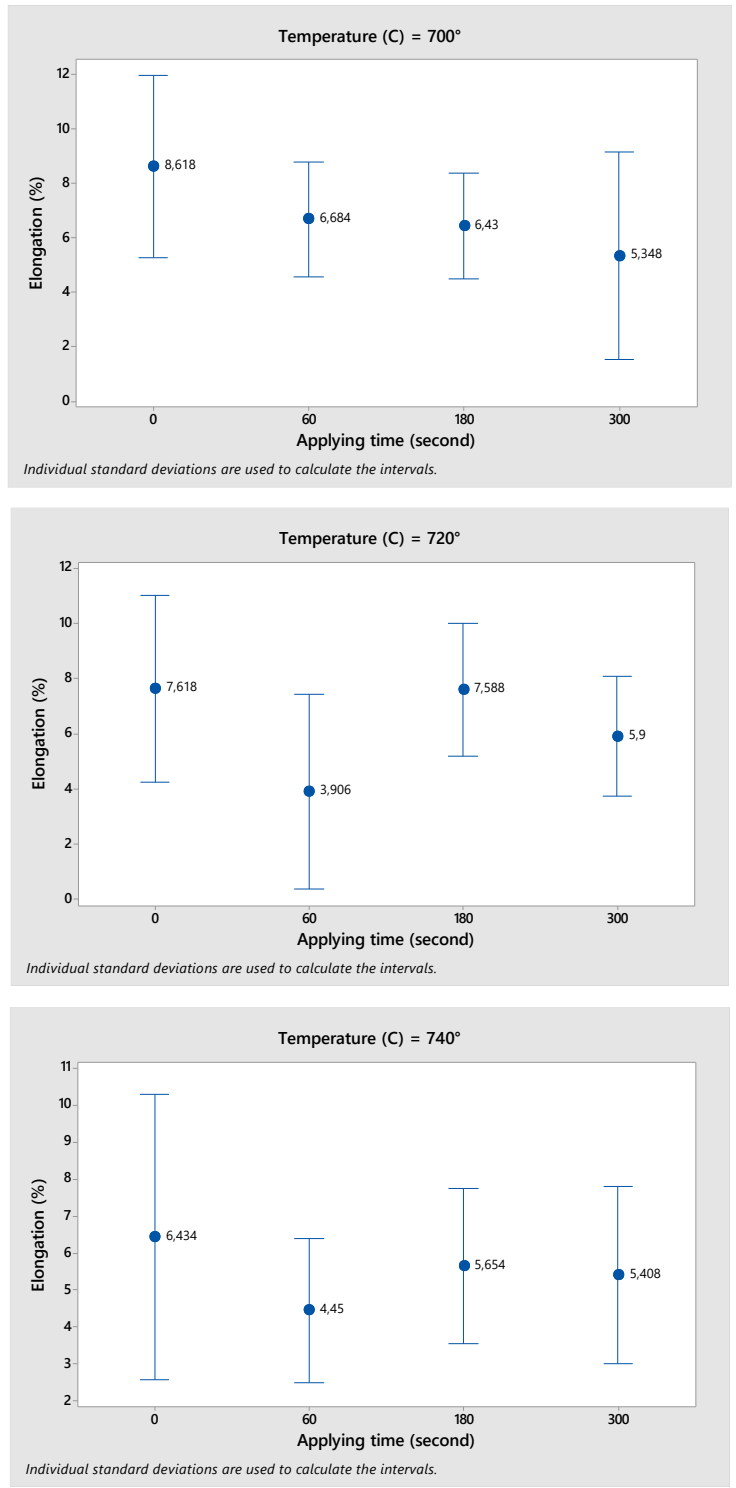

(a) 

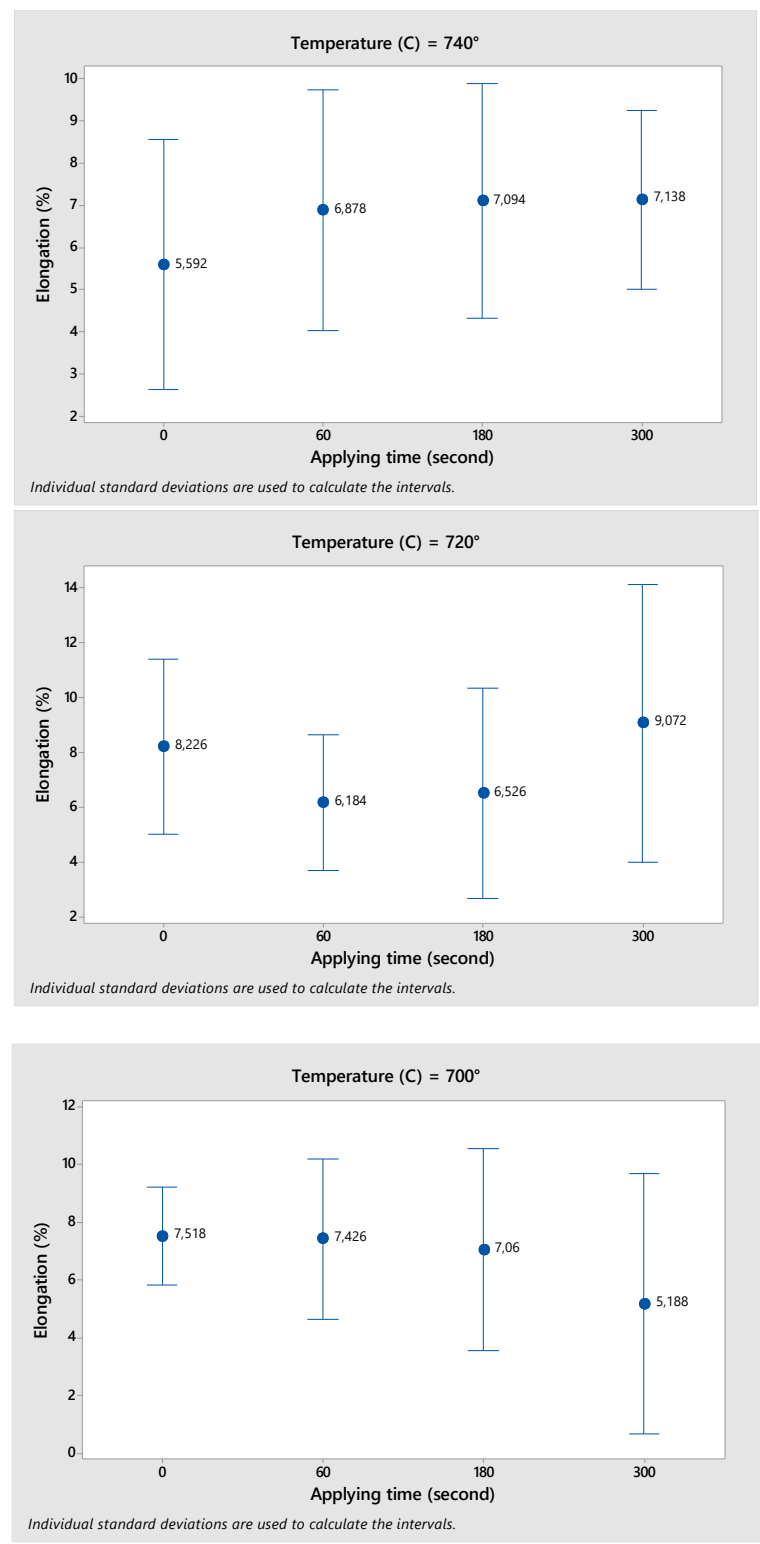

(b)

Fig. 11. Elongation values for a) $2 \mathrm{~kg}$ and b) $4 \mathrm{~kg}$ casting samples.
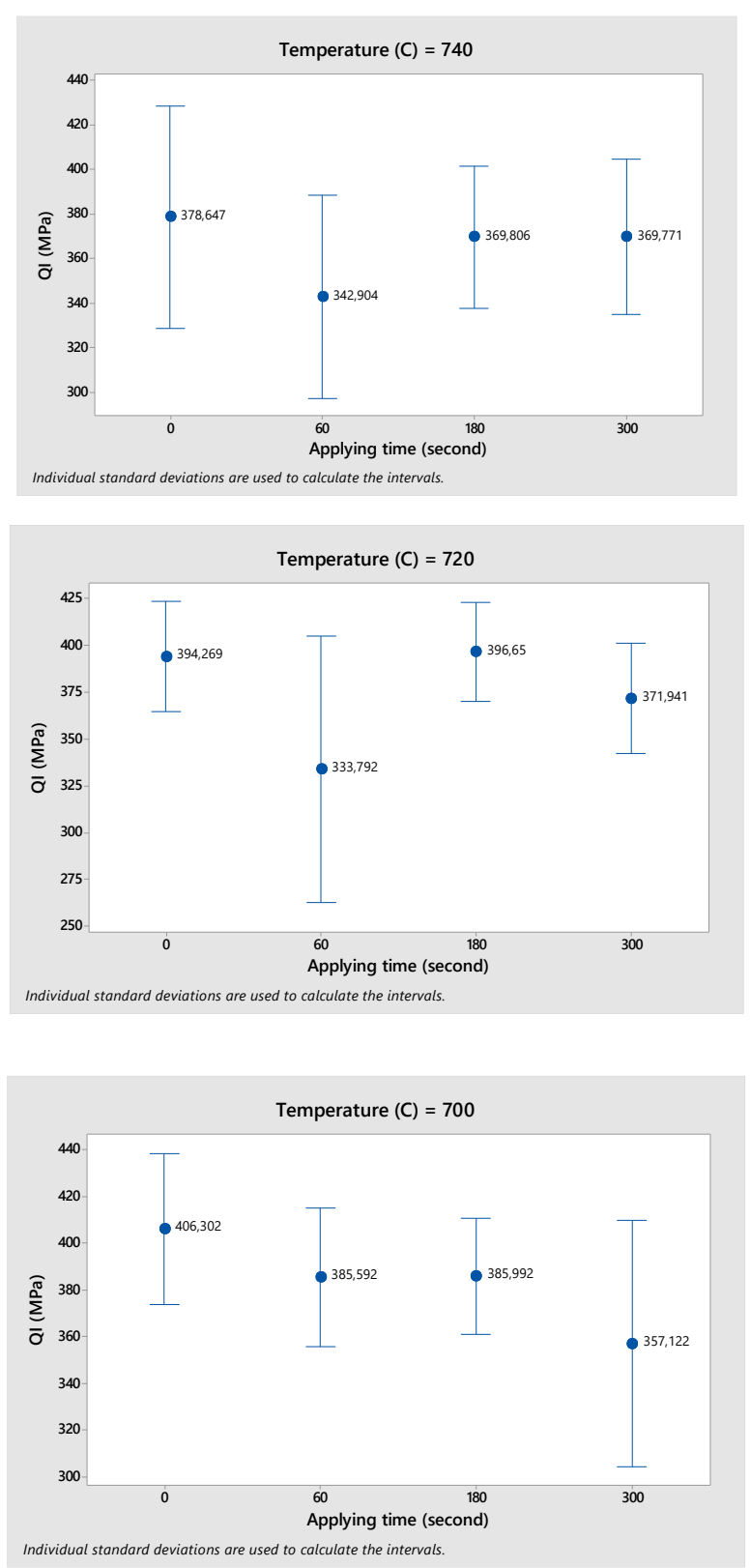

(a) 

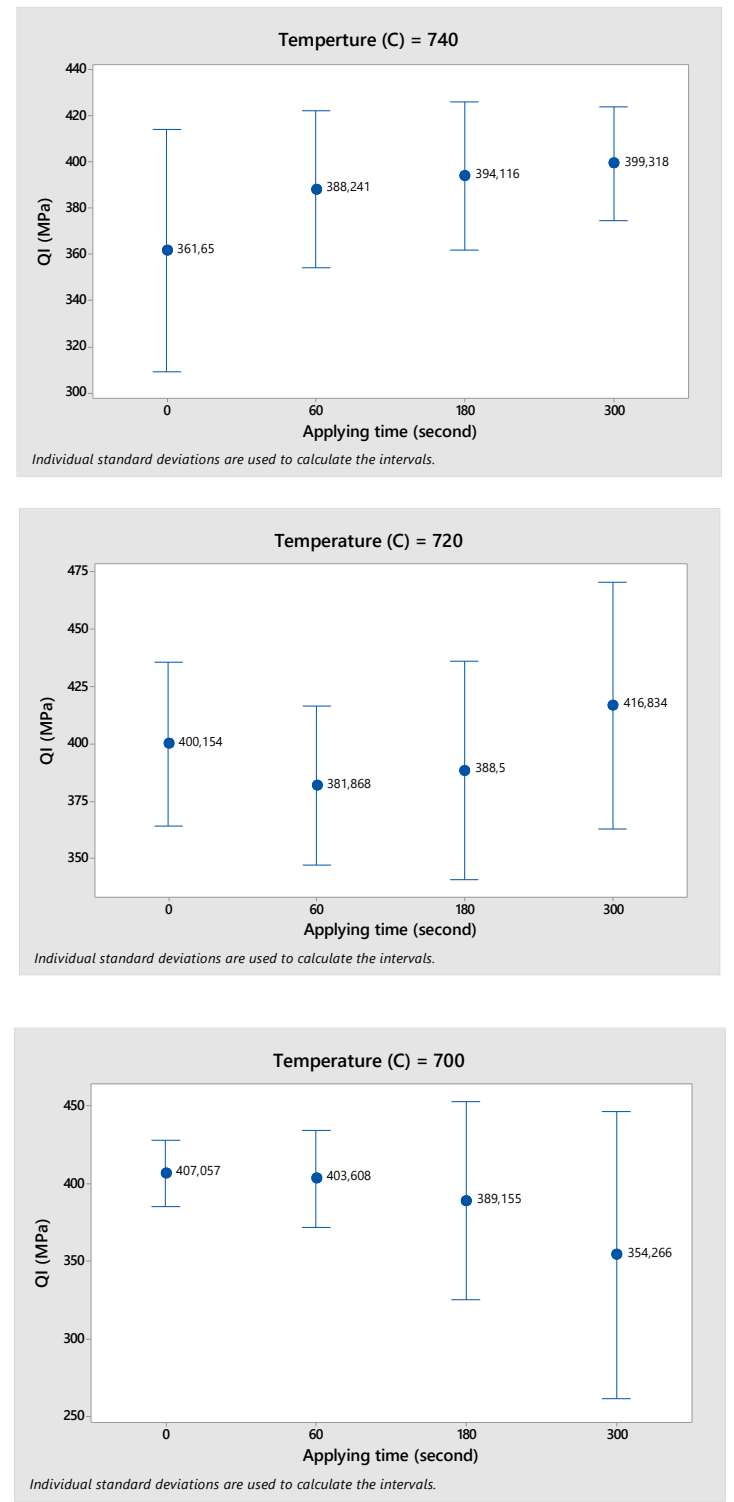

(b)

Fig. 12. Quality index calculated for (a) $2 \mathrm{~kg}$ and (b) $4 \mathrm{~kg}$ casting samples.

\section{Conclusions}

The results of the study can be summarized as follows:

According to the macrostructures, grain size of the sample is getting smaller by increasing ultrasonic treatment duration at all temperature for both $2 \mathrm{~kg}$ and $4 \mathrm{~kg}$ casting samples.

$>$ Microstructural investigation of the $4 \mathrm{~kg}$ casting samples showed that porosity decreases by increasing the ultrasonic treatment duration. But the result is not clear for 2 $\mathrm{kg}$ casting samples.
$>$ Base on the graphics, it can be said that change of the bifilm density, ultimate tensile strength and elongation values fluctuate with different ultrasonic durations at all temperatures for $2 \mathrm{~kg}$ casting samples. However, at $720^{\circ} \mathrm{C}$ and $740^{\circ} \mathrm{C}$ ultimate tensile strength values increase with ultrasonic treatment duration for $4 \mathrm{~kg}$ castings.

$>$ There is an inverse relationship between bifilm density and mechanical test results.

$>$ The maximum values for both ultimate tensile strength and elongation were obtained at $720^{\circ} \mathrm{C}$ after 300 seconds for $4 \mathrm{~kg}$ casting.

\section{Acknowledgment}

This project was supported by SANTEZ 0170.STZ.20131. The authors would like to acknowledge Cenk EKEN for his contribution to this study.

\section{References}

[1] H. Puga, M. Prokic, N. Van Donge: MMM Ultrasonic Metallurgy. http://mastersonics.com/documents/mmm_applications/ultrasonic_metallurgy/MMM-Ultrasonic-MetallurgyAluminium-International.pdf. Accessed 08 May 2018

[2] Birol, Y. (2013). Impact of grain size on mechanical properties of AlSi7Mg0.3 alloy: Materials Science and Engineering A, 559, 394-400.

[3] Nikanorov, S.P., Volkov, M. P., Gurin, V.N., Burenkov, Y. A., Derkachenko, L.I., Kardashev, B.K., Regel, L.L., Wilcox, W.R. (2005). Structural and mechanical properties of Al-Si alloys obtained by fast cooling of a levitated melt: Materials Science and Engineering:A, 390(1-2), 63-69.

[4] YE, H. (2003). An overview of the development of Al-Si-Alloy based material for engine applications: JMEPEG, 12(3), 288-297.

[5] Hawari, A. A., Khader, M., Hasan, W. E., Alijla, M., Manawi, A., Benamour, A. (2014). A life cycle assessment (LCA) of aluminum production process: International Journal of Mechanical, Aerospace, Industrial, Mechatronic and Manufacturing Engineering, 8(4), 704-710.

[6] Xu, H., Meek, T., Han, Q. (2007). Effects of ultrasonic field and vacuum on degassing of molten aluminum alloy: Materials Letters, 61(4-5), 1246-1250.

[7] Xu, H., Jian, X., Meek, T. T., Han, Q. (2004). Degassing of molten aluminum A356 alloy using ultrasonic vibration: Materials letters, 58(29), 3669-3673.

[8] Felberbaum, M., Landry-Désy, E., Weber, L., Rappaz, M. (2011). Effective hydrogen diffusion coefficient for solidifying aluminium alloys: Acta Materialia, 59(6), 2302-2308.

[9] Dispinar, D., Akhtar, S., Nordmark, A., Sabatino, M.D., Arnberg, L. (2010). Degassing, hydrogen and porosity phenomena in A356: Materials Science and Engineering: A, 527(16-17), 3719-3725. 
[10]Dispinar, D., Campbell, J. (2004). Critical assessment of reduced pressure test. Part 1: Porosity phenomena : International Journal of Cast Metals Research, 17(5), 280-286.

[11]Dispinar, D., Campbell, J. (2011). Porosity, hydrogen and bifilm content in : Materials Science and Engineering: A, 528(10-11), 3860-3865.

[12]Dispinar, D., Akhtar, S., Nordmark, A., Syvertsen, F., Sabatino, M.D., Arnberg, L. (2012). Correlation between mechanical properties and porosity distribution of A356 in gravity die casting and low pressure die casting: Advanced Materials Research. Trans Tech Publ, 445, 283-288.

[13]Eskin, D.G., Atamanenko, T.V., Zhang, L., Katgerman, L. (2010). On the mechanism of grain refinement by ultrasonic melt treatment in the presence of transition metals: Essential Readings in Light Metals. 415-419.

[14]Eskin, G. I. (1995). Cavitation mechanism of ultrasonic melt degassing: Ultrasonics Sonochemistry, 2(2), 137-141.

[15]Eskin, G. I. (2001). Broad prospects for commercial application of the ultrasonic (cavitation) melt treatment of light alloys: Ultrasonics Sonochemistry, 8(3), 319-325.

[16]Puga, H., Barbosa, J., Seabra, E., Ribeiro, S., Prokic, M. (2009). The influence of processing parameters on the ultrasonic degassing of molten AlSi9Cu3 aluminium alloy: Materials Letters, 63(9-10), 806-808.

[17]Zhao, L., Pan, Y., Liao, H., Wang, Q. (2012). Degassing of aluminum alloys during remelting: Materials Letters, 66(1), 328-331.

[18]Haghayeghi, R., Bahai, H., Kapranos, P. (2012). Effect of ultrasonic argon degassing on dissolved hydrogen in aluminium alloy: Materials Letters, 82, 230-232.

[19]Puga, H., Barbosa, J., Tuan, N.Q., Silva, F. (2014). Effect of ultrasonic degassing on performance of Al-based components: Transactions of Nonferrous Metals Society of China, 24(11), 3459-3464.

[20]Xu, H., Jian, X., Meek, T., Han, Q. (2016). Ultrasonic degassing of molten aluminum under reduced pressure: Essential Readings in Light Metals. Springer, Cham, 246-250.

[21]Jia, S., Nastac, L. (2013). The influence of ultrasonic stirring on the solidification microstructure and mechanical properties of A356 alloy: Chemical and Materials Engineering, 1(3), 6973.

[22]Li, J., Momono, T., Tayu, Y., Fu, Y. (2008). Application of ultrasonic treating to degassing of metal ingots: Materials Letters, 62(25), 4152-4154.

[23]Khomamizadeh, F., Ghasemi, A. (2004). Evaluation of quality indec of A-356 aluminum alloy by microstructural analysis: Scientia Iranica, 11(4), 386-391.

[24]Czekaj, E., Zych, J., Kwak, Z., Garbacz-Klempka, A. (2016). Quality index of the AlSi7Mg0.3 aluminium casting alloy depending on the heat treatment parameters: Archives of Foundry Engineering, 16(3), 25-28.

[25]Jian, X., Xu, H., Meek, T., Han, Q. (2005). Effect of power ultrasound on solidification of aluminum A356 alloy: Materials Letters, 59(2-3), 190-193.
[26]Das, A., Kotadia, H.R. (2011). Effect of high-intensity ultrasonic irradiation on the modification of solidification microstructure in a Si-rich hypoeutectic Al-Si alloy: Materials Chemistry and Physics, 125(3), 853-859.

[27]Qian, M., Ramirez, A., Das, A., Stjohn, D.H. (2010). The effect of solute on ultrasonic grain refinement of magnesium alloys: Journal of Crystal Growth, 312(15), 2267-2272.

[28]Ramirez, A., Qian, M., Davis, B., Wilks, T., Stjohn, D. (2008). Potency of high-intensity ultrasonic treatment for grain refinement of magnesium alloys: Scripta Materialia, 59(1), 19-22.

[29]Wang, G., Dargusch, M.S., Qian, M., Eskin, D.G., Stjohn, D.H. (2014). The role of ultrasonic treatment in refining the as-cast grain structure during the solidification of an $\mathrm{Al}-2 \mathrm{Cu}$ alloy: Journal of Crystal Growth, 408, 119-124.

[30]Tsunekawa, Y., Suzuki, H., Genma, Y. (2001). Application of ultrasonic vibration to in situ MMC process by electromagnetic melt stirring: Materials \& Design, 22(6), 467-472.

[31]Shusen, W., Longfei, L., Qian, M., Youwu, M., Ping, A. (2012). Degassing effect of ultrasonic vibration in molten melt and semi-solid slurry of Al-Si alloys: China Foundry, 9(3), 201-206.

[32]Sozhamannan, G.G., Balasivanandha Prabu, S., Venkatagalapathy, V.S.K. (2012). Effect of processing parameters on metal matrix composites: stir casting process: Journal of Surface Engineered Materials and Advanced Technology, 2(01), 11.

[33]Dispinar, D., Campbell, J. (2004). Critical assessment of reduced pressure test Part 2: Quantification: International Journal of Cast Metals Research, 17(5), 287-294.

[34]Dispinar, D., Campbell, J. (2006). Use of bifilm index as an assessment of liquid metal quality: International Journal of Cast Metals Research, 19(1), 5-17.

[35]Dispinar, D., Akhtar, S., Nordmark, A., Syvertsen, F., Sabatino, M. D., Arnberg, L. (2012). Tensile properties, porosity and melt quality relation of A356: Supplemental Proceedings: Materials Properties, Characterization, and Modeling, 2, 201-208.

[36]Aybarc, U., Yavuz, H., Dispinar, D., Seydibeyoglu, M.O. (2019). The use of stirring methods for the production of SiCreinforced aluminum matrix composite and validation via simulation studies: International Journal of Metalcasting, 13(1), 190-200.

[37]Yuksel, C., Tamer, O., Erzi, E., Aybarc, U., Cubuklusu, E., Topcuoglu, O., Cigdem, M., Dispinar, D. (2016). Quality evaluation of remelted A356 scraps: Archives of Foundry Engineering, 16(3), 151-156. 